\title{
(Re)living Moments with Momentum: SCENARIO Forum Conference 2017
}

\section{Lane Sorensen}

After passing through the northeastern gate of University College Cork (UCC), my colleagues and I walk the bridge over the river Lee and onto a campus that, were it not for the beautiful wet, grey stone of its buildings and walkways, could just as well be some arm of an enchanting forest near the heart of the city. Although it is my first time here, the verdant space that opens up before me is both new and familiar; my eyes see a place they haven't seen before, but in my mind echo years of conversations and expectations that mark this campus as a bastion of performativity. What a fitting venue for the vibrant palette of talks, workshops, panel discussions, and theater performances that graced the 2017 SCENARIO Forum International Conference, held May 25-28, 2017 in Cork, Ireland to mark the 10-year anniversary of the journal's inception!

Brainchild of the online SCENARIO journal's co-founders, Susanne Even (Indiana University-Bloomington, USA) and Manfred Schewe (UCC), and aided by the talents of its advisory board members, Eucharia Donnery, Micha Fleiner, Dragan Miladinovic, Róisín O'Gorman, and Erika Piazzoli, as well as a number of volunteers who put the help in helpful, this conference brought a diverse array of ideas and research on topics such as poetry, music, dance, human rights, empathy, and interculturality to one momentous venue. That word-momentous - fits the significance of what we as pedagogues, researchers, playwrights, actors, and concerned citizens of the world came together to accomplish under that summer Irish sky: bring momentum to life, art, and learning through the bountiful manifestations of performance. We saw this already on the first day with the hauntingly beautiful interplay of music, words, and light in Killing Stella, performed by Cork-based GAITKRASH, after which the breadth of performative applications was illustrated in the first panel discussion: Towards the creation of (more) performative spaces in education: Perspectives from Architecture, Dance, Drama \& Theatre Studies, Music and Education. A second panel two days later on Performative Arts and Pedagogy: Towards the Development of an International Glossary sought to tie these myriad and colorful threads together.

Featuring presenters from many nations and multiple continents, over 50 theoretical papers in German and English made their debut, with talks ranging from performative spaces for university students in Japan, the role of constructs and gestures in second language acquisition, and understanding archeology with drama to performative teaching of German in Spain, building 
classroom community with drama pedagogy, and embracing the potential of foreign language education in digital and online spaces. The choice of 30 workshops encouraged hands-on, up-and-out-of-your-seat learning and collaboration, allowing us to form cooperative experiences such as bringing poetry to life with movement and still scenes, inhabiting Italian with authentic gestures, or using music and modified composition to enhance foreign language learning. What's more, our two keynote speakers, Wolfgang Hallet (Justus Liebig University Gießen, Germany) and Madonna Stinson (Griffith University Brisbane, Australia), respectively brought us out of the physicality of space into the realms of imagination and signification, and helped us to find hope "as we balance both artistry and teaching in the learning process." And in Ulrike Hentschel's (Universität der Künste Berlin, Germany) plenary address we began our journey with the beginnings of theater education in Germany, tracing the development of its practice to perspectives that offer insights into an intercultural understanding of drama pedagogy today.

We had not only classrooms and drama labs in which to connect with talks and workshops, but also a stage to experience further performances. On Friday night we were informed and entertained by John Crutchfield's one-man show, A Brief History of Metaphysics, followed by the hilarity of the Vienna-based improv trio, "artig", featuring Lino Kleingarn, Alexander Riedmüller, and David Füllekruss. Our hearts were touched a day later by the gravity and vividness of Spurensuche, a collaboration of students from Ernst-Mach Grammar School and Haar Comprehensive School near Munich (led by their teachers Thomas Ritter and Farina Simbeck), who skillfully navigated the atrocities of the Nazi period with original quotes from survivors and information from local, historical documents. With haunting movement, expression, and sound, Spurensuche brought to life human beings who not so long ago witnessed and were victims of unimaginable death. This, perhaps most of all, illustrated to me the undeniable power and good of performativity to resurrect lost moments through movement and drama.

After the last round of tremendous talks, we - organizers and presenters come together again in a room in the Alfred O'Rahilly building to reflect on what has been, days and years past, and what will be for the role of performance in our pedagogical lives. Crossing the bridge to the northeastern gate with me now are not merely colleagues old and new, but friends who carry the meaning of movement with them. Soon again, I hope, we will converge to create, inhabit, and share scenarios to remind ourselves of the worlds within our own. 